\title{
Satisfaction and meaning in life for individuals with traumatic spinal cord injury
}

\section{Satisfação e o sentido da vida para pessoas com lesão medular traumática}

(D) Fabiana Faleiros Santana Castro ${ }^{1}$, (D) Karina de Fátima Bimbatti², (D)Adriane Aparecida Gonçalves de Carvalho ${ }^{2}$ (D) Mariele Lenhari Gonçalves², (D) Filipe Gustavo Lopes³, (D) William Schutt ${ }^{4}$

${ }_{1}^{1}$ Professora, Escola de Enfermagem de Ribeirão Preto da Universidade de São Paulo - EERP-USP ${ }^{2}$ Acadêmica, Escola de Enfermagem de Ribeirão Preto da Universidade de São Paulo - EERP-USP

3 Enfermeiro, Rede Sarah de Hospitais de Reabilitação / Belo Horizonte

4 PhD Student in Clinical Psychology, Case Western Reserve University

\section{Corresponding}

Fabiana Faleiros Santana Castro

E-mail: fabifaleiros@eerp.usp.br

Submitted: November 4, 2020

Accepted: January 6, 2021

\section{How to cite}

Castro FFS, Bimbatti KF, Carvalho AAG, Gonçalves ML, Lopes FG, Schutt W. Satisfaction and meaning in life for individuals with traumatic spinal cord injury. Acta Fisiatr. 2020;27(4):213 219.

DOI: 10.11606/issn.2317-0190.v27i4a177134

\section{(c) (i) (ㅇ)}

(C)2020 by Acta Fisiátrica

This work is licensed under a Creative Commons Attribution 4.0 International

\begin{abstract}
Objective: To analyze meaning in life, satisfaction with life, and the influence of sociodemographic variables in Brazilians with Spinal Cord Injury (SCl). This was a quantitative, cross-sectional, and descriptive study. Participants: Adults with traumatic $\mathrm{SCl}$. Methods: The data were collected through the Survey Monkey platform using the Meaning in Life Questionnaire and the Satisfaction With Life Scale; the sample was composed of adults 18 years old or older with Traumatic $\mathrm{SCl}$. Results: Most of the participants were male (75.5\%), with a mean age of 36.22 . The average score on the Satisfaction With Life Scale was 21.26, which corresponds to the Slightly satisfied category. The mean scores, respectively, for search and presence of meaning in life were 22.61 and 25.32, indicating that most participants find life meaningful even though they don't explicitly search for meaning. There were significant associations between satisfaction with life and the meaning in life. Conclusion: In the rehabilitation process for people with Traumatic $\mathrm{SCl}$, the assessment of satisfaction and the meaning of life must be managed together along with other psychological variables. Considering the complex life context of people suffering from a Traumatic $\mathrm{SCl}$, there is a need for both holistic and individualized understanding during the rehabilitation process.
\end{abstract}

Keywords: Spinal Cord Injuries, Personal Satisfaction, Brazil

\section{RESUMO}

Objetivo: Analisar o sentido da vida, a satisfação com a vida e a influência de variáveis sociodemográficas em brasileiros com Lesão Medular Traumática. Trata-se de um estudo quantitativo, transversal e descritivo com participantes adultos com LM traumática. Método: Os dados foram coletados por meio da plataforma Survey Monkey, utilizando o Questionário de Sentido da Vida e a Escala de Satisfação com a Vida; a amostra foi composta por adultos de 18 anos ou mais com LM traumática. Resultados: A maioria dos participantes era do sexo masculino (75,5\%), com média de idade de 36,22 anos. A pontuação média na Escala de Satisfação com a Vida foi de 21,26, o que corresponde à categoria pouco satisfeito. As pontuações médias, respectivamente, para busca e presença de sentido na vida foram 22,61 e 25,32, indicando que a maioria dos participantes acha a vida com sentido, embora não busque esse sentido explicitamente. Houve associações significativas entre satisfação com a vida e o sentido da vida. Conclusão: $O$ processo de reabilitação de pessoas com LM traumática deve conter a avaliação da satisfação e do sentido de vida em conjunto com outras variáveis psicológicas. O contexto de vida das pessoas que sofrem de uma LM traumática é complexo e há uma necessidade de compreensão holística e individualizada durante o processo de reabilitação.

Palavras-chave: Traumatismos da Medula Espinal, Satisfação Pessoal, Brasil 


\section{INTRODUCTION}

Traumatic $\mathrm{SCl}$ is characterized by a sudden impairment of the structures of the spinal canal, resulting in motor, autonomic, and sensory alterations. It has psychological and social repercussions, and $\mathrm{SCl}$ is often considered among the worst conditions that can affect a human being. When acquiring a traumatic $\mathrm{SCl}$, individuals develop coping strategies in accordance with their life experiences and the relationship(s) they establish with their environment. They usually pass through several phases, including shock, negation, recognition, and adaptation. ${ }^{1,2}$ The implications and impacts of traumatic $\mathrm{SCl}$ on the lives of young people can change the degree of meaning they find in life and their overall satisfaction with life. $\mathrm{SCl}$ can also interfere directly with their coping capacity and success in rehabilitation. ${ }^{3}$

Satisfaction with life depends on judgments made by the individual himself/herself, according to the criteria of the person; it is a cognitive and critical process that involves a comparison of one's own life with the standard that one considers appropriate. ${ }^{4}$ Meaning in life is described as a positive variable indicative of well-being, which facilitates coping and adaptation and always considers the point of view of the individual. Therefore, there is no universal meaning for life, just as there is no formula for finding that meaning. ${ }^{5}$ While satisfaction with life reflects, in part, individual well-being subjectively and considers aspects such as happiness, positive affect, and state of mind, ${ }^{6}$ meaning in life can be understood within positive psychology as the main motivational factor for human beings, as it is directly related to self-determination, positive perception of life, the future and oneself, and the integrative acceptance of adversity. ${ }^{7}$

Despite the relevance and implications of emotion in the process of rehabilitation for people with Traumatic $\mathrm{SCl}$, few Brazilian studies analyze meaning and satisfaction with life in this population. This gap in the literature is noteworthy considering the unique social and demographic characteristics of Brazil.

\section{OBJECTIVE}

The objective of the present study is to analyze meaning in life, satisfaction with life, and the influence of sociodemographic variables for Brazilians with $\mathrm{SCl}$. This project is essential to support future policies and interventions, promote the valuation of life, and improve rehabilitation for young people with $\mathrm{SCl}$. Ultimately, this research could have farreaching effects not only for the individuals suffering from $\mathrm{SCl}$ and their families but for Brazillian society at large.

\section{METHOD}

This is a quantitative, cross-sectional, and descriptive study. It was approved by the Ethics and Research Committee (ERC) at the University of São Paulo (USP) according to Resolution 466/12 of the National Council of Ethics in Research of the Health Department, which deals with ethics in research with human beings under the protocol No. CAAE: 89766518.6.0000.5393.

For data collection, the Ed Diener Satisfaction With Life Scale (SWLS) was used. This scale was validated for the Brazilian
Portuguese and consists of five statements, answered on a Likert scale from one to seven (ranging from "totally disagree" to "strongly agree"). ${ }^{4,8}$ To evaluate meaning in life, Michael F. Steger's Meaning in Life Questionnaire (MLQ) was used, which is composed of 10 statements also on a Likert scale from one to seven (ranging from "absolutely false" to "absolutely true"). ${ }^{5}$

For the characterization of the study participants, a form developed from the Core Dataset and by the International Spinal Cord Society (ISCOS) was used ${ }^{9}$ in addition to sociodemographic data, such as name, date of birth, rehabilitation service attended, level of the $\mathrm{SCl}$, city and state, schooling, profession, and family income. No information about the severity of the injury nor the support of the ventilator at hospital discharge according to ISCOS was provided, as the questionnaire was self-administered and Brazilian participants were not able to answer in-depth questions about $\mathrm{SCl}$. The instruments selected for data collection were transferred to the Survey Monkey platform, generating a virtual version. This virtual version was previously approved in a pre-test with four people.

Participants were contacted through a voluntary Neurorehabilitation research group register for participation in $\mathrm{SCl}$ studies. To disseminate the study, specific links were created for each data collection medium (e-mail and message sending application), which were sent to the 700 registered volunteers.

Links to the virtual questionnaire were available for three months, from March to May 2018, until the minimum sample of 200 participants was reached. Participants who did not complete the questionnaire were excluded (15 participants) as were those outside the inclusion criteria (two participants) due to the cause of their injury. Thus, the present study obtained a sample of 200 adult participants with traumatic SCI.

To analyze descriptive statistics, absolute and relative frequency calculations were performed for qualitative variables, and calculations of central tendency (mean, median) and variability (minimum, maximum, and standard deviation) were performed for quantitative variables. The values of means (m) and medians (md) were presented with the respective standard deviations (sd). The average time to complete the online form was generated by the SurveyMonkey ${ }^{\circledR}$ platform and the categorization of SWLS and MLQ data was suggested by the authors. ${ }^{4,5}$

Level of satisfaction with life was rated as "extremely dissatisfied" for participants who scored between five and nine, "dissatisfied" for those between 10 and 14, "Slightly dissatisfied" for those between 15 and 19, "neutral" for those at 20, "Slightly satisfied" for those between 21 and 25, "satisfied" for those between 26 and 30, and "extremely satisfied" for participants between 31 and $35 .^{4}$

The MQL is composed of two subscales, Presence of Meaning and Search for Meaning, and four possible classifications: a) Score above 24 in both subscales (participant has a presence of meaning and searches for meaning in life); $b$ ) Score above 24 in the Presence subscale and below 24 on the Search scale (participant has a presence of meaning, but does not search for meaning in life); c) Score below 24 in the Presence subscale and above 24 in the Search subscale (participant has no presence of meaning, but searches for meaning in life); d) Score below 24 in both subscales 
(participant has no presence of meaning and does not search for meaning in life). ${ }^{5}$

Statistically, authors used bilateral tests for categorical variables and Fisher's exact test. For comparisons of numerical variables, the Kruskal-Wallis non-parametric test was conducted. A p-value of 0.05 was the threshold for statistical significance.

\section{RESULTS}

The sample was composed of 200 traumatic $\mathrm{SCl}$ participants, aged between 18 and 60 years, with a mean age of 36.22 years old (SD 9.17) and mean age at the time of injury of 26.30 years (SD 8.89). The mean time of injury was 10.66 years (SD 98.99), with a median of $8.12(n=199) .74 .5 \%$ of the sample were male and $25.5 \%$ female. Table 1 shows the sociodemographic data of participants.

Table 1. Distribution of participants according to biosociodemographic data, $(n=200)$, Brazil, 2019

\begin{tabular}{|c|c|c|}
\hline & Frequency & $\%$ \\
\hline \multicolumn{3}{|l|}{ Schooling } \\
\hline $\begin{array}{l}\text { Elementary school ( } 1^{\text {st }} \text { to } 4^{\text {th }} \text { grade, complete or } \\
\text { incomplete) }\end{array}$ & 3 & 1.5 \\
\hline $\begin{array}{l}\text { Elementary school ( } 5^{\text {th }} \text { to } 8^{\text {th }} \text { grade, complete or } \\
\text { incomplete) }\end{array}$ & 17 & 8.5 \\
\hline High school, complete or incomplete & 78 & 39.0 \\
\hline Higher education, complete or incomplete & 83 & 41.5 \\
\hline Specialization/Master's Degree and PhD & 19 & 9.5 \\
\hline \multicolumn{3}{|l|}{ Occupation } \\
\hline Retired or Beneficiary (medical leave, pensioner) & 132 & 66.0 \\
\hline Employed or freelance & 34 & 17.0 \\
\hline Student & 17 & 8.5 \\
\hline Unemployed & 12 & 6.0 \\
\hline Others & 5 & 2.5 \\
\hline \multicolumn{3}{|l|}{ Family income } \\
\hline Up to $\$ 258.92\left(1 \mathrm{MW}^{*}\right)$ & 23 & 11.5 \\
\hline $\begin{array}{l}\text { More than } \$ 258.92 \text { up to } \$ 776.773 \\
\text { (More than } 1 \text { up to } 3 \mathrm{MW}^{*} \text { ) }\end{array}$ & 66 & 33.0 \\
\hline $\begin{array}{l}\text { More than } \$ 776.773 \text { up to } \$ 1294.62 \\
\text { (More than } 3 \text { up to } 5 \mathrm{MW}^{*} \text { ) }\end{array}$ & 45 & 22.5 \\
\hline $\begin{array}{l}\text { More than } \$ 1294,62 \text { up to } \$ 1812.47 \\
\text { (More than } 5 \text { a up to } 7 \mathrm{MW}^{*} \text { ) }\end{array}$ & 17 & 8.5 \\
\hline $\begin{array}{l}\text { More than } \$ 1812.47 \text { up to } \$ 2589.24 \\
\text { (More than } 7 \text { up to } 10 \mathrm{MW}^{*} \text { ) }\end{array}$ & 15 & 7.5 \\
\hline More than $\$ 2589.24$ (More than $10 \mathrm{MW}^{*}$ ) & 12 & 6.0 \\
\hline Not informed and "I don't know" & 22 & 11.0 \\
\hline \multicolumn{3}{|l|}{ Cause of Injury } \\
\hline Traffic accident & 102 & 51.0 \\
\hline Firearm & 41 & 20.5 \\
\hline Diving & 24 & 12.0 \\
\hline Other (Riding, fall of objects, surgery, etc.) & 16 & 8.0 \\
\hline Fall & 16 & 8.0 \\
\hline Melee weapon & 1 & 0.5 \\
\hline \multicolumn{3}{|l|}{ Type of injury } \\
\hline Paraplegic & 104 & 52.0 \\
\hline Tetraplegic & 94 & 47.0 \\
\hline Did not know how to inform & 2 & 1.0 \\
\hline
\end{tabular}

Regarding the level of $\mathrm{SCl}, 47 \%$ had cervical involvement (tetraplegia), 46.5\% thoracic, 5\% sacral (paraplegia) and $1.5 \%$ did not know. Besides that $13 \%$ of participants did not claim to have attended any rehabilitation service and another $13 \%$ claimed to have performed only physiotherapy or occupational therapy. The majority of the participants (60\%) were satisfied with their lives, although only $33.5 \%$ of them were extremely satisfied or satisfied (Fig. 1).
Mean life satisfaction was 21.26 (SD7.6 2), which corresponds to the classification of "Slightly satisfied." The average satisfaction with life was 21.26 (SD 7.62), a score that represents the classification "Slightly satisfied." The minimum and maximum scores obtained were five and 35 , respectively.

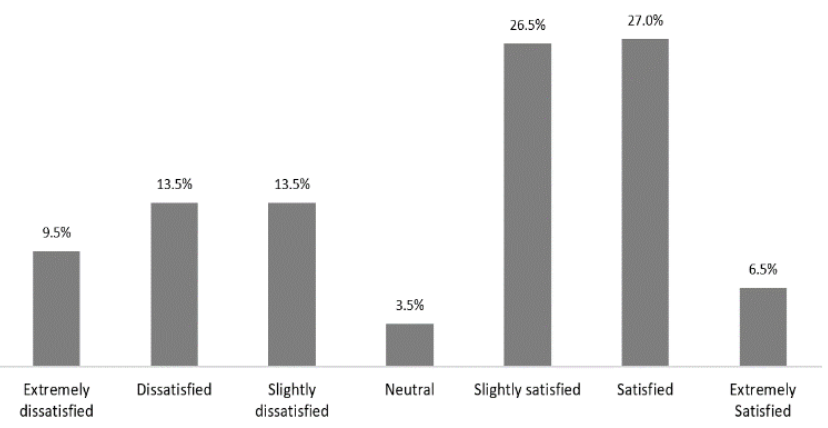

Figure 1. Distribution of participants according to life satisfaction ( $n=200)$, Brazil, 2019

No associations were found between satisfaction with life and other sociodemographic variables such as gender $(p=$ 1.000, Fisher's exact test), income ( $p=0.891$, Fisher's exact test), and type of injury ( $p=0.696$, Fisher's exact test).

Table 2 shows associations between the time of traumatic $\mathrm{SCl}$ and Satisfaction with life, together with the mean, median, and standard deviation of the time of injury in months. There was a statistically significant difference between the time of injury and satisfaction with life $(p=0.026)$.

Table 2. Mean, median, standard deviation, of the injury time according to the level of satisfaction with life $(n=199)$

\begin{tabular}{lcccccc}
\hline Satisfaction with life & M & SD & MD & $\min$ & $\max$ & P-value* \\
\hline Extremely dissatisfied & 89.79 & 83.66 & 61.87 & 10.13 & 372.33 & \\
Dissatisfied & 90.30 & 43.19 & 84.20 & 17.20 & 207.97 & \\
Slightly dissatisfied & 142.32 & 119.87 & 68.93 & 18.20 & 359.10 & \\
Neutral & 99.68 & 39.10 & 115.60 & 28.37 & 150.10 & 0.026 \\
Slightly satisfied & 143.71 & 92.37 & 111.60 & 18.20 & 345.93 & \\
Satisfied & 125.83 & 111.30 & 84.20 & 17.20 & 602.60 & \\
Extremely satisfied & 191.25 & 112.78 & 145.07 & 63.83 & 435.23 & \\
\hline * Kruskal-Wallis & & & & & &
\end{tabular}

Table 3 shows the distribution of participants according to meaning in life through the two MLQ subscales. The mean of the Search subscale was 22.61 (SD 7.81) and the mean of the Presence subscale was 25.32 (SD 7.31). Also, there was no evidence of associations between sociodemographic variables as gender $(p=0.866$, Fisher's exact test), income $(p=0.497$, Fisher's exact test), and type of injury ( $p=0.996$, Fisher's exact test) and meaning in life.

Table 3. Distribution of participants according to meaning in life $(n=200)$, Brazil, 2019

\begin{tabular}{lcc}
\hline \multicolumn{1}{c}{ Meaning in life } & Frequency & $\%$ \\
\hline Has search and presence of meaning in life & 43 & 21.5 \\
Has presence but no search for meaning in life & 74 & 37.0 \\
Has no presence but searches for meaning in life & 51 & 25.5 \\
Has no search nor presence of meaning in life & 32 & 16.0 \\
\hline
\end{tabular}


Table 4 indicates the associations between time of injury and meaning in life, together with the mean, median, and standard deviation of the time of injury in months. No statistically significant difference was found between the time of injury and meaning in life. There was, however, an association between the SWLS and MQL, shown in Table 5. An association was found between the SWLS and MQL ( $p$-value = $0.0005)$; thus, satisfaction with life is associated with meaning in life.

Table 4. Mean, median, and standard deviation of the injury time according to the level of meaning in life $(n=199)$, Brazil, 2019

\begin{tabular}{|c|c|c|c|c|c|c|}
\hline Meaning for life & M & DP & SD & $\min$ & $\max$ & P-value* \\
\hline $\begin{array}{l}\text { Has search and } \\
\text { presence of } \\
\text { meaning in life }\end{array}$ & 127.99 & 91.72 & 92.30 & 17.20 & 359.10 & \\
\hline $\begin{array}{l}\text { Has presence but } \\
\text { no search for } \\
\text { meaning in life }\end{array}$ & 150.15 & 114.01 & 115.60 & 19.23 & 602.60 & \\
\hline $\begin{array}{l}\text { Has no presence } \\
\text { but searches for } \\
\text { meaning in life }\end{array}$ & 105.45 & 81.17 & 85.23 & 17.20 & 327.70 & 0.083 \\
\hline $\begin{array}{l}\text { Has no search } \\
\text { nor presence of } \\
\text { meaning in life }\end{array}$ & 112.94 & 90.27 & 80.13 & 10.13 & 372.33 & \\
\hline
\end{tabular}

Table 5. Associations between the participants' classifications according to meaning in life and satisfaction with life $(n=200)$, Brazil, 2019

\begin{tabular}{|c|c|c|c|c|c|}
\hline $\begin{array}{l}\text { Meaning for life / } \\
\text { Satisfaction with life }\end{array}$ & 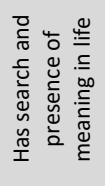 & 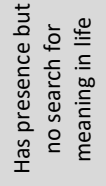 & 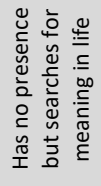 & 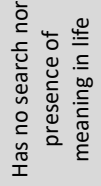 & P-value ** \\
\hline Extremely dissatisfied & 1 & 0 & 10 & 8 & \\
\hline Dissatisfied & 5 & 4 & 11 & 7 & \\
\hline Slightly dissatisfied & 7 & 3 & 12 & 5 & \\
\hline Neutral & 0 & 4 & 2 & 1 & 0.0005 \\
\hline Slightly satisfied & 10 & 20 & 13 & 10 & \\
\hline Satisfied & 17 & 33 & 3 & 1 & \\
\hline Extremely satisfied & 3 & 10 & 0 & 0 & \\
\hline
\end{tabular}

\section{DISCUSSION}

With some exceptions, this study replicates previous sociodemographic findings for individuals with $\mathrm{SCl}$. Most people with $\mathrm{SCl}$ have paraplegia, which corresponds to thoracic, lumbar, and sacral level injuries, and the current data confirm results from previous studies. ${ }^{10,11}$ However, these findings are not homogeneous, as some research has indicated a greater prevalence of tetraplegia (cervical level). ${ }^{12,13}$ In addition, the majority of participants were male and young.

Like previous national and international studies, current data show that $\mathrm{SCI}$ most commonly affects men about 30 years old. ${ }^{14,15}$ Some authors attribut e this profile to the fact that young and masculine individuals are more likely to engage in reckless behaviors.

The primary causes of traumatic $\mathrm{SCl}$ are traffic accidents, followed by violence (firearms) and sports (diving). This applies to Brazil, and Brazilian authors highlight accidents with motorcycles or cars and violence such as firearm injuries as main causes of $\mathrm{SCl}^{10,14}$ In the current study, only $8 \%$ of causes were attributed to falls, while national and international literature suggests there is a higher incidence of falls resulting in $\mathrm{SCl}$ due to the aging of populations; older age is associated with a reduction of causes related to violence as well. ${ }^{11,14}$

This result may be related to the age of the participants in this research, which was between 18 and 60 years old. Our findings suggest that $\mathrm{SCl}$ prevention campaigns in Brazil should consider educational measures for the prevention of violence in and out of traffic. $\mathrm{SCl}$ can have tremendous financial implications at both an individual and societal level. The majority of participants received an annual income of less than \$776.773 (three Brazilian minimum wages, considered in most of Brazil to be lower middle class), which parallels other research, in which around $60 \%$ of participants made less than three minimum wages (MW). ${ }^{16}$

According to the latest Brazilian demographic census, 75\% of the families with a disabled family member live on less than three MW. ${ }^{17}$ This reality is likely a consequence of acquired disabilities since most of the people affected by $\mathrm{SCl}$ stop contributing to their family income after their accident. ${ }^{2,18}$ Also, it is common in Brazil for at least one family member to assume the role of a caregiver after a loved one is significantly injured. This caregiving family member often must stop working, which has consequences not only for the family but for the country.

In these cases, Brazil loses taxpayers and important members of its labor force, highlighting the need for improved rehabilitation services. By adopting as an objective the development of maximum autonomy and the inclusion of people with disabilities in the labor market, both individuals and society at large will benefit.

The majority of participants attained complete or incomplete higher education, making the current sample distinct from other studies. In previous research, the average level of schooling has been lower, with the most subjects failing to complete elementary education. ${ }^{17,19}$ Our findings also contrast with data from the Brazilian Institute of Geography and Statistics, which reports that the average educational level of people with disabilities is lower than that of the typical Brazilian population. ${ }^{20}$

Previous studies have already pointed to the possibility of greater access to online research, by people with higher education, ${ }^{21-23}$ which may be because individuals with higher levels of education generally have better access to health information and research and, consequently, register more often for voluntary participation in medical research. Although $69.3 \%$ of households have Internet access in Brazil, there are still 21,247 thousand households without such access. ${ }^{16}$

While the majority of this study's participants had incomplete or complete higher education and were of an economically active age, $66 \%$ of individuals with $\mathrm{SCl}$ are retired or receive some type of benefit. In the typical Brazilian population, according to the IBGE, men aged 35 to 39 represent the highest level of occupation.

Around $86.5 \%$ of the total number of men working are in this age group. This is significant because individuals of this age who acquire a SCl typically stop working and stop making social security contributions. The importance of investing in rehabilitation policies is evident, as such policies will facilitate 
disabled people's return to the labor market, rather than keeping them on social security; as a bonus, work plays an important role in personal achievement. ${ }^{18}$

The average life satisfaction in this study was 21.26 , which corresponds to "slightly satisfied." In another Brazilian study, in which the same scale was used on a sample of doctors, average life satisfaction was 23.5, which fits the same Likert classification and underscores the adverse working conditions of this professional class. ${ }^{8}$ In addition, the average SWLS score was 21.1 in a survey of patients with Parkinson's disease from several European countries. ${ }^{24}$

This similarity may be due to the dimensions assessed by the SWLS, which broadly conceptualize satisfaction with life, including past, future, profession, family life, and religious experiences. Thus, $\mathrm{SCl}$ does not represent less satisfaction with life compared to other populations that also experience stressors (but that do not have health problems) and populations that present significant loss of autonomy such as Parkinson's.

When analyzing SWLS responses, most participants were slightly satisfied or satisfied with life. However, since satisfaction with life is directly related to health, work, social relationships, and autonomy, ${ }^{25}$ the frequencies of participants who were extremely dissatisfied and dissatisfied with life are also notable. Thus, future research should assess the variables associated with these emotional aspects in addition to investments in rehabilitation centers that provide more comprehensive care.

In a Swedish study, the SWLS was applied to elderly people with $\mathrm{SCl}$. This sample's mean score was 20.7, and no associations were found between satisfaction with life and demographic variables such as gender and the type of injury. ${ }^{26}$

Despite the higher rate of Swedish development relative to Brazil, both countries showed no associations between satisfaction with life and sociodemographic variables. This may be related to aspects of personal coping such as resilience, defined as an adaptation process involving behaviors, thoughts, and actions that can be learned and developed over time in response to traumatic events. ${ }^{27}$ Since acquiring a $\mathrm{SCl}$ can be traumatic, resilience has the potential to favor the individual's overcoming, preserving, and adapting to this new condition.

Unlike these studies, $\mathrm{SCl}$ research in the United States associated life satisfaction with several demographic, social, functional, and clinical characteristics, such as gender, number of readmissions in the last year, years since the injury, disability, mobility, occupation, and social integration. ${ }^{28}$ Some of these variables were related to the rehabilitation service attended, as about $13 \%$ of participants did not attend any rehabilitation service and another $13 \%$ only attended physiotherapy. Much of these individuals, in other words, were not receiving the full benefits of rehabilitation services, and their life satisfaction was suffering as a result.

By better analyzing, reporting, and structuring the support networks of people with $\mathrm{SCl}$ (which could involve utilizing a multidisciplinary mental health team and supporting social/work relations, for example), rehabilitation services could provide many additional benefits for $\mathrm{SCl}$ patients. No associations were found between the level of $\mathrm{SCl}$ injury (i.e. paraplegia and quadriplegia) and satisfaction with life. Another study that assessed quality of life in this population similarly found no association between these variables, suggesting that life satisfaction is complex and that variables such as race, culture, and resilience also need to be investigated..$^{29}$ On the other hand, a Norwegian study of individuals with incomplete $\mathrm{SCl}$ identified significantly greater life satisfaction among the participants who were exercising regularly. ${ }^{30}$

Another study with Americans with $\mathrm{SCl}$ suggested that impairment (level of injury) contributed indirectly to life satisfaction, through its impact on motor disability. ${ }^{28}$ In this sense, the literature shows that the severity of the injury is not related to psychological well-being, but to the perceived loss of physical skills and the generation of meaning and purpose in life, which are variables directly related to positive adaptation after $\mathrm{SCl}^{31}$ It is therefore imperative that the rehabilitation process is thorough and not prematurely discontinued, and that it incorporates the expertise of multiple professionals.

An association was found between injury time and life satisfaction. This finding replicates previous studies, in which the same association was found with other satisfaction scales and may be related to the ability to adapt to new conditions over time. ${ }^{17}$ Rehabilitation plays an important role in the coping process, since the establishment of goals and the resumption of lost activities, as well as the reduction of dependence, leads to a consequent improvement in quality of life. ${ }^{32,33}$ These factors are directly related to life satisfaction as perceived by the individual. Considering the self-criterion of this variable, results confirm that individuals with $\mathrm{SCl}$ can rebuild and redefine their lives.

Most participants experienced meaning in their lives, but most did not actively search for meaning. One interpretation of this finding, according to the MQL, is that participants generally experienced meaning in their life, but did not explore such meaning. ${ }^{34}$ This finding is important for people with $\mathrm{SCl}$, since having a well-defined life purpose is considered a component of psychological well-being. ${ }^{35}$ However, not searching for meaning in life, when analyzed in isolation, can be problematic; some studies indicate that searching is related to the perception of a future goal and can motivate the finding of strategies to achieve their goal, ${ }^{36}$ and can represent a protective factor that promotes resilience. ${ }^{37}$ In addition, $16 \%$ of the participants did not search for or have meaning present in their lives. Even though they did not represent the majority, this is a notable portion of the sample since having a defined meaning protects against suicide. Therefore, the rehabilitation process must find ways to help these people find meaning.

Most of the sample felt their lives were meaningful but did not search for meaning: search and presence scores were 22.61 and 25.32, respectively. These scores are lower than those found in adolescents without $\mathrm{SCl}$ in another Brazilian survey, in which averages were 25.88 and 27.00 , respectively. ${ }^{38}$ In another international study, the MQL was administered to undergraduate psychology students and a correlational analysis between search and presence was conducted.

The authors concluded that, for some people, more searching may decrease presence, but at the same time, searching was correlated with extensive cognitive measures. ${ }^{39}$

These studies all indicate the importance of considering sample populations, as the presence of $\mathrm{SCl}$ probably influences how presence and search for meaning relate. Experiencing 
meaning in life and searching for a satisfactory life are needs important during adulthood. Even in the face of changing roles such as a decline in physical capacity and an accumulation of interpersonal losses, people can understand their experiences and their purposes. ${ }^{40}$ In this sense, measures are necessary both for the prevention of $\mathrm{SCl}$, which mainly affects young people, and for the establishment of rehabilitation programs that consider psychological variables. This study shows that further research is needed to investigate variables that make up the complex context of rehabilitation for people with $\mathrm{SCl}$.

There were several notable limitations to thie study. Aside from typical cross-sectional constraints, collecting data through a virtual platform may have limited the participation of a portion of the Brazilian population without access to the Internet. As such, future studies should include data from people without Internet access. Future studies should also attempt to include more in-depth information about the severity and nature of the participants' $\mathrm{SCl}$.

\section{CONCLUSION}

This study shows that variables related to mental health for those who have suffered traumatic $\mathrm{SCl}$, such as life satisfaction and meaning in life, are associated. The rehabilitation process for people with $\mathrm{SCl}$ should incorporate an evaluation of overall satisfaction and meaning in life, in addition to other important psychological variables.

The environmental and broader life context for those with traumatic $\mathrm{SCl}$ is complex and more research is needed to understand this debilitating condition. Future studies should aim towards developing more individualized and holistic treatment, focusing on improving the autonomy and the integrated participation of people with $\mathrm{SCl}$ in society.

\section{REFERENCES}

1. Brasil. Ministério da Saúde. Diretrizes de atenção à pessoa com lesão medular. 2 ed. Brasília: Ministério da Saúde; 2015.

2. Kalyani $\mathrm{HH}$, Dassanayake $\mathrm{S}$, Senarath U. Effects of paraplegia on quality of life and family economy among patients with spinal cord injuries in selected hospitals of Sri Lanka. Spinal Cord. 2015;53(6):446-50. Doi: https://doi.org/10.1038/sc.2014.183

3. Borges AMF, Brignol P, Schoeller SD, Bonetti A. Percepção das pessoas com lesão medular sobre a sua condição. Rev Gaúcha Enferm. 2012;33(3):119-125. Doi: https://doi.org/10.1590/S1983-14472012000300016

4. Diener E, Emmons RA, Larsen RJ, Griffin S. The Satisfaction With Life Scale. J Pers Assess. 1985;49(1):71-5. Doi: https://doi.org/10.1207/s15327752jpa4901 13

5. Steger MF, Frazier P, Oishi S, Kaler M. The meaning in life questionnaire: Assessing the presence of and search for meaning in life. J Couns Psychol. 2006;53(1):80-93. Doi: https://doi.org/10.1037/0022-0167.53.1.80

6. Joia LC, Ruiz T, Donalisio MR. Condições associadas ao grau de satisfação com a vida entre a população de idosos. Rev Saude Publica. 2007;41(1):131-8. Doi: https://doi.org/10.1590/s0034-89102007000100018

7. Frankl VE. A vontade de sentido: fundamentos e aplicações da logoterapia. São Paulo: Paulus; 2011.
8. Gouveia VV, Barbosa GA, Andrade EO, Carneiro MB. Medindo a satisfação com a vida dos médicos no Brasil. J Bras Psiquiatr. 2005;54(4):298-305.

9. Biering-Sørensen F, Charlifue S, DeVivo M, Noonan V, Post $M$, Stripling $T$, et sl. International Spinal Cord Injury Data Sets. Spinal Cord. 2006;44(9):530-4. Doi: https://doi.org/10.1038/sj.sc.3101930

10. Schoeller SD, Grumann ARS, Martin AC, Forner S, Sader LT, Nogueira GC. Conhecer para cuidar: caracterização de pessoas com lesão medular atendidas em um centro de reabilitação. Fisioter Mov.2015;28(1):77-83. Doi: http://dx.doi.org/10.1590/0103-5150.028.001.A008

11. Rodríguez-Meza MV, Paredes-Cruz M, Grijalva I, RojanoMejía D. Clinical and demographic profile of traumatic spinal cord injury: a Mexican hospital-based study. Spinal Cord. 2016;54(4):266-9. Doi: http://dx.doi.org/10.1038/sc.2015.164

12. Tate DG, Forchheimer M, Rodriguez G, Chiodo A, Cameron $A P$, Meade $M$, et al. Risk factors associated with neurogenic bowel complications and dysfunction in spinal cord injury. Arch Phys Med Rehabil. 2016;97(10):1679-86. Doi: http://dx.doi.org/10.1016/j.apmr.2016.03.019

13. Ning GZ, Mu ZP, Shangguan L, Tang Y, Li CQ, Zhang ZF, et al. Epidemiological features of traumatic spinal cord injury in Chongqing, China. J Spinal Cord Med. 2016;39(4):45560.

Doi:

http://dx.doi.org/10.1080/10790268.2015.1101982

14. Rabeh SAN, Nogueira PC, Caliri MHL. Bowel function and the relationship with functional independence of individuals with spinal cord injury. Coluna/Columna. 2013;12(2):153-6. Doi: https://doi.org/10.1590/S180818512013000200013

15. Joseph C, Delcarme A, Vlok I, Wahman K, Phillips J, Nilsson Wikmar L. Incidence and aetiology of traumatic spinal cord injury in Cape Town, South Africa: a prospective, population-based study. Spinal Cord. 2015;53(9):692-6. Doi: https://doi.org/10.1038/sc.2015.51

16. Instituto Brasileiro de Geografia e Estatística. Acesso à internet e à televisão e posse de telefone móvel celular para uso pessoal: 2016. Rio de Janeiro: IBGE; 2016.

17. Silva JCF. Reabilitação de pessoas com lesão medular traumática: estudo do intestino neurogênico e sua relação com a qualidade de vida, satisfação e estilo de vida [Dissertação]. Ribeirão Preto: Universidade de São Paulo, Escola de Enfermagem de Ribeirão Preto; 2017. Doi: https://doi.org/10.11606/D.22.2018.tde-28032018-162226

18. Nogueira GC, Schoeller SD, Ramos FR, Padilha MI, Brehmer LC, Marques AM. The disabled and public policy: the gap between intentions and actions. Cien Saude Colet. 2016;21(10):3131-42. Doi: https://doi.org/10.1590/1413$\underline{812320152110.17622016}$

19. Fumincelli L, Mazzo A, Martins JCA, Henriques FMD, Orlandin L. Quality of life of patients using intermittent urinary catheterization. Rev Lat Am Enfermagem. 2017;25:e2906. Doi: https://doi.org/10.1590/1518$\underline{8345.1816 .2906}$

20. Instituto Brasileiro de Geografia e Estatística. Censo demográfico 2010: características gerais da população, religião e pessoas com deficiência. Rio de Janeiro: IBGE; 2012. 
21. Faleiros F, Käppler C, Pontes FAR, Silva SSC, Goes FSN, Cucick CD. Uso de questionário online e divulgação virtual como estratégia de coleta de dados em estudos científicos. Texto Contexto Enferm, 2016; 25(4):e3880014. Doi: http://dx.doi.org/10.1590/010407072016003880014

22. Smith $A B$, King $M$, Butow $P$, Olver I. A comparison of data quality and practicality of online versus postal questionnaires in a sample of testicular cancer survivors. Psychooncology. 2013;22(1):233-7. Doi: http://dx.doi.org/10.1002/pon.2052

23. van den Berg $M H$, Overbeek $A$, van der Pal $H J$, Versluys $A B$, Bresters $D$, van Leeuwen $F E$, et al. Using web-based and paper-based questionnaires for collecting data on fertility issues among female childhood cancer survivors: differences in response characteristics. J Med Internet Res. 2011;13(3):e76. Doi: http://dx.doi.org/10.2196/jmir.1707

24. Lucas-Carrasco R, Den Oudsten BL, Eser E, Power MJ. Using the satisfaction with life scale in people with Parkinson's disease: a validation study in different European countries. ScientificWorldJournal. 2014;2014:680659.

Doi: http://dx.doi.org/10.1155/2014/680659

25. Tate DG, Forchheimer M. Quality of life, life satisfaction, and spirituality: comparing outcomes between rehabilitation and cancer patients. Am J Phys Med Rehabil. 2002;81(6):400-10. Doi: http://dx.doi.org/10.1097/00002060-200206000-00002

26. Battalio SL, Silverman AM, Ehde DM, Amtmann D, Edwards KA, Jensen MP. Resilience and function in adults with physical disabilities: an observational study. Arch Phys Med Rehabil. 2017;98(6):1158-1164. Doi: http://dx.doi.org/10.1016/j.apmr.2016.11.012

27. American Psychological Association. Building your resilience [text on the Internet]. Washington DC: APA; c2012 [cited 2020 Nov 04]. Available from: https://www.apa.org/topics/resilience

28. Dijkers MP. Correlates of life satisfaction among persons with spinal cord injury. Arch Phys Med Rehabil. 1999;80(8):867-76.

Doi: http://dx.doi.org/10.1016/s0003-9993(99)90076-x

29. Jörgensen S, Iwarsson S, Lexell J. Secondary health conditions, activity limitations, and life satisfaction in older adults with long-term spinal cord injury. PM R. 2017;9(4):356-366.

Doi:
30. Lannem AM, Sørensen M, Frøslie KF, Hjeltnes N. Incomplete spinal cord injury, exercise and life satisfaction. Spinal Cord. 2009;47(4):295-300. Doi: http://dx.doi.org/10.1038/sc.2008.117

31. Roon-Cassini TA, St Aubin E, Valvano A, Hastings J, Horn P. Psychological well-being after spinal cord injury: perception of loss and meaning making. Rehabil Psychol. 2009;54(3):306-14.

Doi: http://dx.doi.org/10.1037/a0016545

32. França ISX, Coura AS, Sousa FS, Almeida PC, Pagliuca LMF. Qualidade de vida em pacientes com lesão medular. Rev Gaúcha Enferm. 2013;34(1):155-63. Doi: https://doi.org/10.1590/S1983-14472013000100020

33. Nas K, Yazmalar L, Şah V, Aydın A, Öneş K. Rehabilitation of spinal cord injuries. World J Orthop. 2015;6(1):8-16. Doi: http://dx.doi.org/10.5312/wjo.v6.i1.8

34. Steger MF. The Meaning in Life Questionnaire [text on the Internet]. Fort Collins: Laboratory for the Study of Meaning and Quality of Life; c2010 [cited 2020 Nov 04]. Available from: http://www.michaelfsteger.com/

35. Ryff CD, Keyes CL. The structure of psychological wellbeing revisited. J Pers Soc Psychol. 1995;69(4):719-27. Doi: http://dx.doi.org/10.1037//0022-3514.69.4.719

36. del Río-González AM, Herrera AN. Desarrollo de un instrumento para evaluar perspectiva de tiempo futuro en adolescentes. Avances en Medición. 2006;4(1):47-60.

37. Mccabe K, Barnett D. First comes work, then comes marriage: future orientation among African American young adolescents. Family Relations. 2000;49(1):63-70.

38. Luz JMO, Murta SG, Aquino TAA. Avaliação de resultados e processo de um intervenção para promoção de sentido da vida em adolescentes. Trends Psychol. 2017; 25 (4): 1795-1811. Doi: http://dx.doi.org/10.9788/tp2017.4$14 \mathrm{pt}$

39. Steger MF, Kashdan TB, Sullivan BA, Lorentz D. Understanding the search for meaning in life: personality, cognitive style, and the dynamic between seeking and experiencing meaning. J Pers. 2008;76(2):199-228. Doi: http://dx.doi.org/10.1111/j.1467-6494.2007.00484.x

40. Steger MF, Oishi S, Kashdan TB. Meaning in life across the life span: Levels and correlates of meaning in life from emerging adulthood to older adulthood. J Posit Psychol. 2009; 4(1):43-52. Doi: https://doi.org/10.1080/17439760802303127 